\title{
URGENSI PENDIDIKAN MULTIKULTURAL DALAM MASYARAKAT PLURAL (STUDI KASUS DI KOTA SINGKAWANG)
}

\author{
URGENCY OF MULTICULTURAL EDUCATION \\ IN PRURAL SOCIETY \\ (CASE STUDY IN SINGKAWANG CITY)
}

\author{
Karel Juniardi dan Emusti Rivasintha Marjito \\ Program Studi Pendidikan Sejarah IKIP PGRI Pontianak \\ Jln. Ampera No. 88, Pontianak \\ kareljuniardi82@gmail.com dan emustirivasintha87@gmail.com
}

Diterima tanggal 2 Februari 2018

Disetujui tanggal 22 Mei 2018

\begin{abstract}
This study aims to determine the general picture, cultural tradition, and the urgency of multicultural education in the school of Singkawang City. This research applies qualitative research method in form of stuck case study strategy. Sources of data applied are informants, places and events, documents, and literature. Data validity applied triangulation and data interactive analysis techniques. Based on the research, it is known that multicultural education in Singkawang City is important to give tolerance attitude in plural society life. One form of education is in the form of cultural ceremonies that are included as subject in school.
\end{abstract}

Keywords: education, multicultural, and plural.

\begin{abstract}
Abstrak
Penelitian ini bertujuan untuk mengetahui gambaran umum, tradisi budaya, dan urgensi pendidikan multikultural di sekolah Kota Singkawang. Penelitian ini menggunakan metode penelitian kualitatif dengan bentuk strategi studi kasus terpancang. Sumber data yang digunakan yaitu informan, tempat dan peristiwa, dokumen, serta literatur. Validitas data menggunakan triangulasi dan teknik analisa data menggunakan teknik analisis interaktif. Berdasarkan hasil penelitian diketahui bahwa pendidikan multikultural di Kota Singkawang penting untuk memberikan sikap toleransi dalam kehidupan plural masyarakatnya. Salah satu bentuk pendidikan berupa penyelenggaraan upacara tradisi budaya yang dimasukkan dalam materi pelajaran di sekolah.
\end{abstract}

Kata kunci: pendidikan, multikultur, dan plural. 


\section{A. PENDAHULUAN}

Dalam zaman globalisasi ini, baik ekonomi maupun budaya, kajian tentang penduduk dunia yang menyangkut karakteristik dan dinamika penduduk, tipe-tipe perubahan sosialbudaya, dan faktor-faktor yang ditimbulkan makin marak. Kajian tersebut ternyata melibatkan berbagai ilmu sosial, antara lain demografi, ekonomi, sosiologi, geografi, psikologi, politik dan lain sebagainya (Widiarto dan Suwarso, 2007:62-63). Salah satu di antara obyek kajian itu adalah perihal masyarakat plural yang ada di Kota Singkawang.

Kota Singkawang merupakan satu dari 14 kabupaten/kota yang ada di Provinsi Kalimantan Barat. Awalnya, Singkawang adalah sebuah desa bagian dari wilayah Kesultanan Sambas sebagai tempat singgah para pedagang dan penambang emas dari daerah Monterado (Monterado kini menjadi sebuah kecamatan di Kabupaten Bengkayang, letaknya di sebelah Timur Singkawang). Para penambang dan pedagang yang kebanyakan berasal dari negeri Cina. Sebelum mereka menuju Monterado, terlebih dahulu beristirahat di Singkawang. Begitu pula para penambang emas di Monterado sering beristirahat di Singkawang untuk melepas kepenatannya. Singkawang juga menjadi tempat transit pengangkutan hasil tambang emas yang akan dijual ke luar daerah. Sebelum barang hasil tambang dibawa ke luar Singkawang untuk dijual, barang tersebut disimpan di gudang-gudang untuk kemudian dikapalkan. Di saat menunggu barang tersebut untuk dikapalkan, para pedagang berhari-hari menetap di Singkawang. Hal inilah yang menyebabkan Singkawang menjadi semakin ramai oleh aktivitas perdagangan.

Asal mula penamaan Singkawang ialah dari penyebutan para pendatang, yakni San Kew Jong (bahasa Hakka) yang berarti Gunung Mulut Lautan. Penyebutan tersebut didasari oleh kondisi geografis Singkawang berbatasan langsung dengan Laut Natuna serta terdapat pegunungan dan sungai, dimana airnya mengalir dari pegunungan melalui sungai sampai ke muara laut. Secara geografis, Singkawang tergolong daerah yang relatif terbuka, khususnya daerah pesisir, paling cepat mengalami perubahan. Dengan semakin baiknya sarana dan prasarana transportasi, hubungan antarkelompok masyarakat semakin intensif dan semakin sering pula mereka melakukan pembauran (Rustanto, 2016:43-44). Para pendatang dari etnis Tionghoa ini membaur dengan penduduk yang telah menetap lebih dahulu di sekitar Singkawang yakni penduduk Melayu dan Dayak. Interaksi yang terjadi berupa hubungan ekonomi seperti masalah jual beli dan perdagangan sampai hubungan sosial seperti perkawinan antar-etnis.

Perkembangan Desa Singkawang cukup menjanjikan dengan keadaan geografisnya sehingga para penambang tersebut beralih profesi menjadi petani dan pedagang yang pada akhirnya 
tinggal serta menetap di Singkawang (Rahmayani, 2010:13). Hal ini sejalan dengan menurunnya deposit emas di Monterado yang menyebabkan para penambang emas kemudian menggeluti bidang usaha tanaman perdagangan, seperti sayur mayur, beras, dan berbagai bahan pangan lainnya. Sistem bercocok tanam padi ini diperkirakan mulai dipraktikkan menjelang akhir abad ke18. Hasil bercocok tanam di Singkawang dan sekitarnya tersebut ternyata tidak dapat memenuhi kebutuhan pangan penduduk Monterado sehingga pada tahun 1830 terdapat sekitar 12.000 pikul beras yang didatangkan melalui pelabuhan Singkawang (Usman, 2008:23). Beralihnya mata pencaharian penduduk dari petambang ke petani dan pedagang di Singkawang membuat daerah ini semakin lama semakin berkembang. Peralihan mata pencaharian ke bidang pertanian sangat dimungkinkan karena wilayah Singkawang subur dan cocok untuk ditanami tanaman pangan seperti padi. Dari hasil panen padi kemudian diperjualbelikan meskipun tidak mencukupi untuk memenuhi kebutuhan penduduk di sekitar Singkawang sehingga perlu didatangkan beras dari luar daerah. Adanya potensi bidang pertanian ini menyebabkan proses peralihan profesi dari petambang ke petani dan kemudian pedagang menjadi lancar. Peluang ekonomi dalam bentuk pekerjaan baru ini mendatangkan minat etnis Tionghoa untuk menetap di Singkawang.

Kota Singkawang resmi dibentuk pada tanggal 17 Oktober 2001 berdasarkan Undang-Undang Nomor 12 Tahun 2001 tentang Pembentukan Kota Singkawang. Penduduk yang menetap di kota ini multietnis antara lain etnis Tionghoa, Dayak, Melayu, Bugis, Jawa, Madura, dan Sunda. Kota ini juga dijuluki "kota seribu kelenteng" karena banyak berdiri kelenteng yang merupakan tempat peribadatan etnis Tionghoa. Keberadaan kelenteng di tanah air dan termasuk di Kota Singkawang sudah sejak ratusan tahun silam, semenjak orang-orang Tionghoa merantau ke Indonesia pada masa akhir pemerintahan Dinasti Tang. Setelah menetap, mereka memperkenalkan kebudayaan, termasuk misi keagamaan dengan mendirikan tempat peribadatan yang disebut kelenteng (Yoest, 2008:9). Kelenteng dalam kehidupan masyarakat Tionghoa berfungsi sebagai tempat religius dan sosial. Setiap permukiman Tionghoa selalu dilengkapi dengan kelenteng (Rahmayani, 2014:119). Kelenteng sering disebut juga dengan vihara. Di Singkawang kelenteng atau vihara yang terkenal adalah Vihara Tri Dharma Bumi Raya, Vihara Dewi Kwan Im, Vihara Surga Neraka. Selain tempat peribadatan, etnis Tionghoa di Singkawang juga mengadakan upacara tradisi Imlek, Cap Go Meh, dan Sembahyang Kubur. Tradisi ini erat kaitannya dengan ajaran Konfusius yang dipegang teguh oleh etnis Tionghoa di perantauan. Ajaran ini tetap dibawa dan diterapkan di tempat menetap etnis Tionghoa yang baru guna melestarikan budaya dan keyakinan yang berasal dari tanah moyang mereka. 
Etnis Tionghoa juga membuat keramik yang pembuatannya masih tradisional, yaitu menggunakan tungku naga. Industri keramik di Singkawang dikelola secara turun temurun dan masih bertahan hingga sekarang. Kebanyakan industri ini berada di daerah Sakkok Kelurahan Sedau Kecamatan Singkawang Selatan. Hasil keramik Singkawang diperjualbelikan ke pasaran domestik bahkan ada yang merambah sampai ke mancanegara. Keramik hasil buatan Sakok sangat menarik dan artistik bergaya Dinasti Ming. Ciri khasnya terletak pada desain Singkawang ini sering dijadikan oleholeh bagi para wisatawan yang datang ke Singkawang.

Selain Tionghoa, etnis lain seperti etnis Dayak juga sering mengadakan upacara Naik Dango apabila mereka telah selesai memanen padi. Ada pula upacara Saprahan pada etnis Melayu sebagai wujud rasa syukur kepada Tuhan atas berkah yang telah diberikan.

Uraian di atas menunjukkan bahwa pengkajian tentang masyarakat plural yang ada di Kota Singkawang penting untuk dilakukan. Selain itu kajian ini penting akibat merasuknya nilai-nilai Barat yang masuk melalui arus globalisasi ke kalangan masyarakat Indonesia merupakan ancaman bagi budaya asli yang mencitrakan lokalitas khas daerah-daerah di negeri ini. Budaya konvensional yang menempatkan tepo seliro, toleransi, keramah-tamahan, penghormatan pada yang lebih tua juga tergerus oleh pergaulan bebas dan sikap individual- istik yang dibawa oleh arus globalisasi. Dalam situasi demikian, kesalahan dalam merespon globalisasi bisa berakibat pada lenyapnya budaya lokal. Kesalahan dalam merumuskan strategi mempertahankan eksistensi budaya lokal juga bisa mengakibatkan budaya lokal semakin ditinggalkan masyarakat yang kini kian gandrung pada budaya yang dibawa arus globalisasi (Alma, 2010:143). Berdasarkan uraian di atas, makalah ini membahas permasalahan sebagai berikut (1) bagaimana gambaran umum Kota Singkawang?, (2) bagaimana tradisi budaya di Kota Singkawang?, (3) bagaimana urgensi pendidikan multikultural di sekolah Kota Singkawang?

Penelitian ini dilakukan di Kota Singkawang, Kalimantan Barat. Kota ini memiliki kehidupan plural yang perlu dijaga dan dilestarikan. Penelitian dimulai September sampai dengan Desember 2017. Penelitian ini menggunakan jenis penelitian kualitatif, data yang dikumpulkan terutama berupa kata-kata, kalimat atau gambar yang memiliki arti lebih bermakna dan mampu memacu pemahaman yang lebih nyata daripada sekadar sajian angka atau frekuensi (Sutopo, 2006:40). Atas dasar bentuk penelitian tersebut, maka penelitian ini dilakukan dengan tiga tahap, yaitu tahap orientasi, tahap eksplorasi, dan tahap member check (pemeriksaan data-data).

Adapun strategi yang digunakan adalah studi kasus terpancang tunggal karena memfokuskan pada kasus, yaitu urgensi pendidikan multikultural dalam 
masyarakat plural di Kota Singkawang. Selain alasan tersebut, peneliti membatasi pada rumusan masalah sebelum ke lapangan. Studi deskriptif merupakan penelitian yang dimaksudkan untuk mengumpulkan informasi mengenai status gejala yang ada, yaitu keadaan gejala menurut apa adanya pada saat penelitian dilakukan. Dalam kegiatan akan digali berbagai data yang berhubungan dengan urgensi pendidikan multikultural masyarakat plural di Kota Singkawang, Kalimantan Barat.

Sumber data yang digunakan dalam penelitian ini, yaitu (1) informan. Informan mencakup tokoh masyarakat Tionghoa, Melayu, dan lainnya serta pelaku tradisi budaya di Kota Singkawang; (2) tempat pelaksanaan penelitian di Kota Singkawang; (3) dokumen berupa dokumen surat kabar, foto, dan lain-lain; dan (4) studi literatur untuk melengkapi teori dan pembahasan. Teknik pengumpulan data yang digunakan, yaitu (1) observasi langsung yang bersifat partisipasi pasif berupa pengamatan objek penelitian; (2) wawancara mendalam; (3) mengkaji dokumen; dan (4) analisis literatur. Validitas data yang dikembangkan adalah teknik triangulasi sumber dan triangulasi metode. Triangulasi data (sumber) menjadi pilihan karena dapat memanfaatkan jenis sumber data yang berbeda, sedangkan triangulasi metode dilakukan untuk lebih memantapkan hasil pengumpulan data yang kemudian hasilnya digunakan untuk membuat kesimpulan data yang lebih kuat validitasnya (Sutopo, 2006:91-96).

\section{B. HASIL DAN BAHASAN}

\section{Gambaran Umum} Kota Singkawang

Kota Singkawang berada di pesisir Barat Pulau Kalimantan, tepatnya di Provinsi Kalimantan Barat. Daerah ini memiliki keunikan, baik dari sisi geografis maupun sosial budaya. Wilayah ini berada di pesisir laut dan berlatar belakang beberapa gunung antara lain Gunung Poteng, Gunung Pasi, Gunung Raya, dan Gunung Sakok. Kondisi geografis ini melatari penamaan Singkawang oleh masyarakat Tionghoa, yaitu berasal dari kata San Kew Jong yang secara harfiah berarti Gunung Mulut Lautan. Sementara bagi masyarakat Melayu yang merupakan bagian pemukim di Singkawang mengatakan Singkawang berasal dari kata Tengkawang yang merupakan jenis buah yang banyak tumbuh di daerah itu. Penamaan tersebut kiranya berhubungan dengan perdagangan tengkawang pada masa Hindia Belanda yang menjadi salah satu komoditas yang menguntungkan (Rahmayani, 2010:13).

Pada saat ini, Kota Singkawang secara administratif memiliki luas 504 $\mathrm{km}^{2}$, dibagi menjadi 5 (lima) wilayah kecamatan meliputi 26 kelurahan. Secara geografis terletak antara $108^{\circ}$ $52^{\prime} 14,19^{\prime \prime}$ sampai dengan $109^{\circ} 09^{\prime}$ 44,22" Bujur Timur dan $00^{\circ} 44^{\prime}$ 57,57" sampai dengan $01^{\circ} 00^{\prime} 48,65^{\prime \prime}$ Lintang Utara. Sebelah utara berbatasan dengan Kecamatan Selakau Kabupaten Sambas, sebelah selatan berbatasan dengan Kecamatan Sungai Raya Kabupaten Bengkayang, sebelah barat 
berbatasan dengan Laut Natuna dan sebelah Timur berbatasan dengan Kecamatan Samalantan Kabupaten Bengkayang (https://id.m.wikipedia.org /wiki/Kota_Singkawang, diakses pada 13 Oktober 2017).

Berdasarkan keadaan demografis, Kota Singkawang dapat dikategorikan sebagai salah satu pecinan di Indonesia karena mayoritas penduduknya adalah orang Hakka (sekitar 42\%) atau Tionghoa. Selebihnya, Singkawang dihuni oleh orang Melayu, Dayak, Jawa, Madura, dan pendatang lainnya. Populasi penduduknya terus mengalami peningkatan setiap tahunnya dengan laju pertumbuhan penduduk pada tahun 2006 adalah 5,6\%. Hal ini dikarenakan Singkawang sudah menjadi kota perdagangan dalam segi produksi dan distribusi sehingga menarik penduduk lain untuk tinggal di Singkawang. Dan pada tahun 2010 , tercatat penduduk Singkawang sudah mencapai 186.462 jiwa (Laporan Sensus Penduduk Badan Pusat Statistik, 2010).

Masyarakat Tionghoa termasuk masyarakat Hakka yang menetap di memiliki ikatan yang kuat terhadap kehidupan religiusnya termasuk pula di dalamnya konsep kosmologi. Kepercayaan orang Tionghoa pada umumnya dipengaruhi oleh ajaranajaran tradisional mereka yaitu Taoisme, Budhisme, dan Konfusianisme. Setelah sempat dipaksa untuk berada dalam "keseragaman" oleh pemerintah Orde Baru, Konfusianisme mulai kembali berkembang di wilayah Singkawang dan sekitarnya pada masa pascareformasi. Ajaran ini menekankan konsep hidup ren dan li. Ren (kebajikan) mempunyai arti mengasihi sesama, sedangkan $l i$ diartikan sebagai tata krama atau adat istiadat. Ajarannya mengandung arti untuk menguasai diri serta mengikuti adat istiadat. Kelenteng (vihara, toapekong) mulai muncul dan beraktivitas secara terang-terangan (Taniputera, 2008: 104).

Di samping itu, terdapat juga ajaran Taoisme yang memengaruhi dalam tata perilaku masyarakat Tionghoa. Ajaran yang disebarkan oleh Lao Tze ini lebih menekankan pada filosofi hidup yang wajar seperti gerakan alam (Tohardi, 2003:61). Konsep inilah yang dibawa oleh orang Tionghoa yang merantau ke Singkawang dalam menyesuaikan diri dengan lingkungan barunya termasuk bagaimana mereka membangun permukiman di tempat barunya. Ada pula konsep samsara di dunia untuk mendapatkan kenikmatan di nirwana merupakan konsep lain yang dibawa oleh ajaran Budha (Budhisme). Kesederhanaan orang Tionghoa ketika sedang berusaha meraih sesuatu yang diinginkannya merupakan salah satu contoh betapa ajaran ini lekat dalam keseharian orang Tionghoa (Rahmayani, 2010: 33). Dari berbagai ajaran tersebut, orang Tionghoa melaksanakan dengan teguh upacara Imlek, Cap Go Meh, dan Sembahyang Kubur. 


\section{Tradisi Budaya di Kota Singkawang}

Kehadiran masyarakat Tionghoa di Singkawang membawa beberapa tradisi budaya yang sampai sekarang masih dilaksanakan, diantaranya perayaan Cap Go Meh dan tradisi membuat keramik. Dihapuskan Instruksi Presiden (Inpres) Nomor 14 Tahun 1967 oleh pemerintahan Presiden Abdurrahman Wahid (Gus Dur), semua aktivitas bernuansa Tionghoa mulai marak diperlihatkan. Bentuk aktivitas tersebut berupa atraksi seni, aktivitas religi sampai dengan ragam kuliner dipertunjukkan di Singkawang.

Setelah 'reformasi', masyarakat Tionghoa memperoleh keleluasaan untuk melakukan segala aktivitas mereka dengan tenang. Perayaan Imlek dan Cap Go Meh yang mempertunjukkan berbagai atraksi seni, budaya, dan religi merupakan salah satu citra Tionghoa yang sedang dikembangkan. Hal ini terlihat dari kesemarakan perayaan tersebut di beberapa daerah di Kalimantan Barat seperti di Kota Singkawang. Aktivitas semacam itu merupakan nilai tradisional yang dilestarikan dan sudah menjadi kegiatan tetap setiap tahunnya di Kota Singkawang.

Etnis Tionghoa yang menjadi penduduk mayoritas di Kota Singkawang terbiasa menjalankan tradisi Cap Go Meh pasca-reformasi 1998. Etnis Tionghoa yang merayakan tradisi tersebut adalah pendatang dan penduduk Kota Singkawang serta sekitarnya. Kebanyakan dari mereka adalah orang Hakka (orang Khek) dan sedikit dari orang Teochiu (Rahmayani, 2010: 26). Etnis Hakka yang dikenal teguh memegang tradisi nenek moyang inilah yang membuat nama Singkawang mencuat dan mendunia setelah menyelenggarakan festival Cap Go Meh yang keunikannya tidak ditemukan di belahan dunia manapun. Hal ini karena festival Cap Go Meh di Kota Singkawang representasi dari perpaduan antara ritual, kebudayaan, dan kesenian dari etnis Tionghoa yang berakulturasi dengan etnis Dayak dan etnis Melayu.

Kepercayaan dan tradisi budaya Cap Go Meh berlanjut dan berkembang secara turun-temurun, baik di dataran Cina maupun di perantauan-perantauan seluruh dunia termasuk di Indonesia umumnya serta Kota Singkawang di Kalimantan Barat khususnya. Kemeriahan Cap Go Meh yang unik di Kota Singkawang adalah dalam atraksi Tatung. Atraksi keliling kota oleh Tatung dilakukan dengan tujuan mengusir roh-roh jahat yang mengganggu perayaan Cap Go Meh (Usman, 2008: 82). Pengusiran roh-roh jahat dan peniadaan kesialan dalam Cap Go Meh disimbolkan dalam pertunjukkan Tatung. Tatung adalah media utama Cap Go Meh yang dipenuhi dengan mistik dan menegangkan karena banyak orang kesurupan dan orang-orang inilah yang disebut Tatung. Kebudayaan ini dapat disebut sebagai adat istiadat yang biasanya berfungsi sebagai tata kelakuan yang mengatur, mengendali, 
dan memberi arah kepada kelakuan dan perbuatan manusia dalam masyarakat (Koentjaraningrat, 1993: 5-6).

Kota Singkawang terkenal juga dengan industri keramiknya. Industri keramik di Kota Singkawang yang sudah berdiri sejak zaman Kolonial Belanda adalah perusahaan keramik Dinamis, Tajau Mas, dan Sinar Terang. Perusahaan keramik Dinamis berada di Sakkok tepatnya di Jalan Raya Sedau, didirikan oleh Bong Fo Ong yang sebelumnya telah menjadi pengrajin keramik di Serawak Malaysia (Soedarto, 1994: 21). Pembakaran keramik dilakukan dengan tungku naga yang panjangnya sekitar dari 30 meter. Keramik yang dibuat pada awalnya adalah produk untuk memenuhi keperluan sehari-hari masyarakat seperti mangkok, piring, tempayan, serta guci. Kebiasaan masyarakat Tionghoa dalam mengawetkan makanan menjadikan produk-produk tersebut diminati. Tidak hanya masyarakat Tionghoa, masyarakat Melayu dan Dayak pun menggunakannya dalam keperluan sehari-hari mereka. Masyarakat Dayak menggunakan guci sebagai tempat menyimpan tuak (minuman khas Dayak), peralatan pada ritual keagamaan, menyimpan tulang belulang leluhurnya. dan sebagai hadiah perkawinan. Selain itu, keramik Singkawang juga digunakan untuk merebus obat Cina, serta tempat ari-ari (plasenta) yang dikubur setelah seorang anak lahir (Rahmayani, 2009: 35-38).

Dalam proses pembuatannya, perusahaan keramik mempekerjakan pekerja dari berbagai etnis yang ada di sekitar Sakkok. Pekerja dari etnis Madura biasanya dipekerjakan pada persediaan bahan bakar yaitu kayu karet. Pembentukan keramik, pemotongan dan pengolahan (penginjakan) kaolin dilakukan oleh para pekerja Tionghoa. Biasanya, para pekerja ini mempunyai pekerjaan tetap sebagai petani. Mereka digaji perhari atau perminggu (Rahmayani, 2009: 3739). Pembuatan keramik mengalami perkembangan melalui berbagai inovasi seperti penggunaan warna-warna baru untuk glasir dan penggunaan beragam zat kimia untuk mendukung pewarnaan (Soedarto, 1994: 39). Proses pembakaran juga mengalami perkem-bangan dengan alasan kepraktisan maka penggunaan tungku elektrik dalam pembakaran menjadikan fungsi tungku naga semakin berkurang. Tungku elektrik dianggap lebih menghemat waktu dan pembakaran dapat dilakukan secara otomatis (Rahmayani, 2009: 4748).

\section{Urgensi Pendidikan Multikultural di Sekolah}

\section{Kota Singkawang}

Tradisi Cap Go Meh dan industri keramik di Kota Singkawang merupakan sebuah keunggulan lokal. Keunggulan lokal adalah segala sesuatu yang merupakan ciri khas kedaerahan yang mencakup aspek ekonomi, budaya, teknologi informasi, komunikasi, dan ekologi. Sumber lain mengatakan bahwa keunggulan lokal ialah hasil bumi, kreasi seni, tradisi, 
budaya, pelayanan, jasa, sumber daya alam, sumber daya manusia, dan lainnya yang menjadi keunggulan suatu daerah. Keunggulan lokal juga merupakan suatu proses dan realisasi peningkatan nilai dari suatu potensi daerah sehingga menjadi produk jasa atau karya lain yang bernilai tinggi, bersifat unik, dan memiliki keunggulan komparatif (Dedidwitagama dalam Asmani, 2012: 53-54).

Berdasarkan pemaparan tentang potensi tradisi budaya yang ada di Kota Singkawang, yaitu perayaan tradisi Cap Go Meh yang diselenggarakan setiap bulan Februari atau Maret dan adanya industri keramik yang masih menggunakan tungku naga dalam proses pembuatannya. Hal tersebut dapat menjadi pengembangan secara sosial bagi masyarakat Kota Singkawang. Kedua potensi tersebut dapat dijadikan sebagai sumber belajar bagi peserta didik di sekolah.

Sebagaimana diketahui bahwa penduduk Kota Singkawang terdiri atas berbagai macam etnis, dapat dikatakan bahwa penduduk Kota Singkawang adalah plural. Dalam masyarakat plural, seringkali timbul masalah atau konflik dengan berbagai sebab, seperti perbedaan kepentingan, politik, ataupun pribadi. Hal ini karena dimanapun manusia hidup, konflik di antara individu, kelompok, dan nasional pasti timbul (Banks, 2012: 143).

Menurut sejarah, konflik yang terjadi di Kota Singkawang sudah terjadi pada masa kolonial Belanda sewaktu orang-orang Tionghoa dari
Monterado mencoba menyerang kedudukan Kesultanan Sambas yang didominasi oleh etnis Melayu pada pertengahan abad ke-19 M. Dengan bantuan Belanda, konflik ini bisa diredam tahun 1854 (Andri, et al., 2008: 102). Sejak peristiwa tersebut hubungan antara etnis Melayu dengan etnis Tionghoa tidak lagi hanya sekadar hubungan ekonomi tetapi juga politik karena etnis Tionghoa ingin berperan melalui pembentukan daerah otonom, meskipun secara de jure masih dalam lingkup kekuasaan Kesultanan Sambas.

Selain dengan Melayu, etnis Tionghoa juga telah menjalin hubungan dengan etnis Dayak. Masyarakat Tionghoa merupakan salah satu dari kelompok masyarakat pelaku kebudayaan yang relatif tersebar di hampir setiap wilayah Kalimantan Barat, baik itu di perkotaan maupun di pedesaan atau pedalaman. Bahkan, antara masyarakat Tionghoa dengan masyarakat sekitar, khususnya Dayak sudah terbangun hubungan sosial yang cukup kuat, yang dilatarbelakangi oleh persamaan budaya, saling ketergantungan secara ekonomi, dan hubungan perkawinan atau amalgamasi. Kemudian muncullah istilah sobat, menunjuk pada pengertian karib atau saudara yang diberikan oleh masyarakat Dayak terhadap Tionghoa.

Namun, setelah satu peristiwa eksesif demontrasi pengusiran dengan kekerasan yang dilakukan masyarakat Dayak terhadap Tionghoa dari wilayah pedalaman atau yang lebih dikenal dengan istilah demonstrasi Cina oleh 
Dayak tahun 1967. Saat ini, mereka lebih banyak terkonsentrasi diwilayah perkotaan, khususnya di Kota Singkawang dan Kota Pontianak.

Peristiwa ini berhubungan dengan peristiwa pemberontakan PGRSParaku dan bentuk politisasi kelompok masyarakat oleh negara, sebagai akibat dari perubahan konstelasi politik dalam negeri serta berubahnya sikap politik luar negeri Indonesia terhadap Malaysia saat itu. Hal ini tidak ada hubungannya dengan proses interaksi sosial budaya yang terjadi antar kedua kelompok masyarakat tersebut, pada gilirannya justru menghasilkan satu bentuk perubahan relatif struktur sosial dan kebudayaan masyarakat Kalimantan Barat saat itu (Andri, et al., 2008: 4546). Ketimpangan antarsuku tersebut tidak dapat diselesaikan oleh pemerintahan Presiden Soeharto saat itu. Hal ini ditunjukkan oleh konflik berbasis budaya yang segera mencuat setelah Presiden Soeharto mundur (Agusta, 2014: 74).

Untuk mengharmoniskan hubungan sosial di antara penduduk Kota Singkawang yang plural, upaya yang dilakukan antara lain melalui pemanfaatan potensi tradisi budaya Cap Go Meh dan industri keramik yang ada di Kota Singkawang. Pertama, dalam kegiatan Cap Go Meh terdapat etnis lain yang terlibat yaitu etnis Melayu, dalam Cap Go Meh antara lain sebagai pemain Barongsai, pembawa tandu yang dinaiki oleh Tatung, pembawa alat musik yang mengiringi atraksi Tatung. Demikian juga etnis Dayak turut memeriahkan perayaan Cap Go Meh dengan berpartisipasi sebagai pemain Tatung.

Kedua, dalam industri keramik, terbatas pada hubungan sosial untuk kepentingan ekonomi, seperti penggunaan orang Madura sebagai pekerja di industri keramik di Kota Singkawang. Hal ini dilakukan agar seluruh masyarakat Kota Singkawang merasa memiliki keramik sebagai produk kebanggaan mereka meskipun dibuat oleh etnis lain.

Selain itu, untuk mempererat hubungan sosial antaretnis juga dilakukan kegiatan tradisi budaya, seperti:

1) Melibatkan organisasi kemasyarakatan dari berbagai etnis di Kota Singkawang antara lain dari Majelis Adat Budaya Melayu (MABM) dan Dewan Adat Dayak (DAD), serta undangan, partisipan, kepanitiaan dalam perayaan Cap Go Meh.

2) Menyajikan pagelaran tari kreasi yaitu Tari Tidayu (Tionghoa, Dayak, dan Melayu) sebagai simbol persatuan dan toleransi terhadap multikulturalisme di Kota Singkawang dalam perayaan Cap Go Meh.

3) Memasukkan perayaan Cap Go Meh, dan tradisi budaya etnis yang lain sebagai muatan lokal dalam kurikulum sebagai pendidikan multikultural di sekolah-sekolah dari tingkat dasar sampai menengah. Pendidikan multikultural di sekolah bertujuan membentuk manusia budaya dan menciptakan manusia 
berbudaya (berperadaban); mengajarkan nilai-nilai luhur kemanusiaan, nilai-nilai bangsa, dan nilai-nilai kelompok etnis (Mahfud, 2016: 187). Dalam pelaksanaannya, pengembangan pendidikan multikultural harus didasarkan pada prinsip: 1) Keragaman budaya menjadi dasar dalam menentukan filsafat; 2) Keragaman budaya menjadi dasar dalam mengembangkan berbagai komponen kurikulum seperti tujuan, konten, proses, dan evaluasi; 3) Budaya di lingkungan unit pendidikan adalah sumber belajar dan obyek studi yang harus dijadikan bagian dari kegiatan belajar siswa; dan 4) Kurikulum berperan sebagai media dalam mengembangkan kebudayaan daerah dan kebudayaan nasional (Haningsih, 2005: 10). Pendidikan multikultur dapat diadopsi untuk solusi masalah kebhinekaan. Pendidikan multikultur dapat membangun nasionalisme Indonesia di tengah tantangan global (Tukiran, 2014: 29-36). Sehingga warga Kota Singkawang dapat menjadi masyarakat multikultur yang terdiri atas suku, ras, dan agama yang berbeda-beda tetapi secara bersamasama berfungsi untuk membangun, membina kebudayaan sebagai kebudayaan nasional (Ratna, 2016:183). Tradisi Cap Go Meh dapat juga berfungsi dalam menjaga nilai- nilai kearifan lokal. Menurut Koentjaraningrat (1990), kearifan lokal adalah pandangan hidup, ilmu pengetahuan dan berbagai strategi kehidupan yang berwujud aktivitas yang dilakukan masyarakat lokal dalam menjawab berbagai masalah dalam pemenuhan kebutuhan mereka yang meliputi seluruh unsur kehidupan meliputi agama, pandangan hidup, ilmu pengetahuan dan teknologi, organisasi sosial, ekonomi, bahasa, dan kesenian (Supriatna, 2017: 62). Tradisi Cap Go Meh mempunyai nilai-nilai universal seperti toleransi, religi, menghargai perbedaan dan lainnya sebagai bagian dari nilai-nilai pendidikan multikultural.

Nilai-nilai budaya dalam multikultural mengandung unsur keluhuran yang tinggi dan harus dikenalkan dan ditanamkan dalam diri siswa sejak dini (Utama, 2013:165). Pendidikan multikultural harus diajarkan sejak dini sehingga anak mampu menerima dan memahami perbedaan budaya yang berdampak pada perbedaan usage (cara-cara), folkways (kebiasaan), mores (aturan-aturan), dan customs (adat-istiadat). Pendidikan multikul-tural akan menanamkan cara hidup menghormati, tulus, dan toleran terhadap keanekaragaman budaya yang hidup di tengah-tengah masyarakat plural (Supardi, 2014: 92). Dalam masyarakat plural diperlukan nilai-nilai kebersamaan, toleransi, dan keberadaban. Dengan demikian tercipta keharmonisan dalam kehidupan 
Ada beberapa strategi pembelajaran, di antaranya adalah strategi pembelajaran inkuiri sosial. Strategi ini merupakan perkembang-an pemikiran Hilda Taba dan Richard Suchman, yang kemudian dikembangkan lebih jauh oleh Byron Massialas dan Benyamin Cox. Strategi inkuiri sosial merupakan strategi pengembangan kemampuan siswa untuk penyelidikan dan merefleksikan sifat kehidupan sosial terutama sebagai latihan hidup langsung di masyarakat. Pembelajaran inkuiri ini bertolak dari suatu keyakinan bahwa dalam rangka pengembangan kemampuan siswa secara independen, penyelidikan masalahmasalah sosial, sangat diperlukan sebagai partisipasi aktif warga negara/ warga masyarakat. Dalam hal ini sekolah mempunyai peranan yang aktif dalam perbaikan masyarakat sebagai "creative reconstruction" tentang sosiokultural. Sekolah tidak hanya berkewajiban untuk memelihara nilai-nilai di masyarakat, tetapi juga harus memberikan keaktifan kepada siswa untuk kritis dalam menghadapi masalah-masalah sosial yang timbul (Supardan, 2015: 203-204).

Hal ini sejalan dengan pedagogik kritis yang menekankan pada kekritisan menghadapi masalah-masalah pendidikan. Melalui pembelajar-an inkuiri maka masalah-masalah sosial di Kota Singkawang, terutama masalah intoleransi, dapat diminimalisasi. Disharmonis antar individu maupun kelompok yang biasanya disebabkan oleh sikap prejudis (memandang sebuah kelompok secara general, padahal di dalam kelompok itu sebenarnya terdapat berbagai macam variasi), stereotip (jenis penilaian terhadap sifat-sifat sebagai ciri khas sebuah kelompok), dan diskriminasi (perlakuan yang tidak adil terhadap orang atau kelompok tertentu) dapat dihilangkan (Nuriyanto, 2014: 21). Peserta didik diajarkan untuk aktif dan kritis apabila terjadi sesuatu yang bertentangan dengan nilai-nilai kemanusiaan, keagamaan, dan multikulturalisme.

Tradisi Cap Go Meh sebagai pengembangan sumber belajar dalam pembelajaran IPS sangat cocok sekali bila menggunakan pembelajaran inkuiri dalam proses pembelajarannya dengan berbasis pendidikan multikulturalisme. Strategi pembelajaran inkuiri dalam pelaksanaannya terbagi menjadi enam tahapan yaitu: 1) tahap orientasi, dengan menetapkan pokok bahasan masalah sosial yang tidak terlalu luas; 2) tahap hipotesis, merumuskan hipotesis yang dapat dijadikan acuan inkuiri; 3) tahap definisi, menjelaskan istilah-istilah yang ada dalam hipotesis; 4) tahap eksplorasi, menguji hipotesis dengan logika deduksi, yaitu menghubungkan hipotesis dengan implikasi dan asumsi-asumsinya; 5) tahap pembuktian, membuktikan hipotesis dengan fakta-fakta di 
masyarakat; dan 6) tahap generalisasi, menyatakan pemecahan masalah yang dapat digunakan (Supardan, 2015: 204).

Dari enam tahapan di atas, maka apabila ingin menyelidiki bagaimana tradisi Cap Go Meh sebagai pengembangan sumber belajar dalam pembelajaran IPS dapat menjadi solusi bagi masalahmasalah sosial di Kota Singkawang dapat menggunakan strategi pembelajaran inkuiri. Dari tahap pertama yaitu masalah intoleransi dalam kehidupan masyarakat Kota Singkawang, maka diajukan hipotesis tentang pembelajaran tradisi Cap Go Meh sebagai pengembangan sumber belajar dalam pembelajaran IPS berbasis pendidikan multikultural, kemudian peserta didik turun ke lapangan untuk melakukan penyelidikan dengan cara berinteraksi dengan orang atau narasumber atau melakukan observasi sewaktu pelaksanaan tradisi Cap Go Meh di Kota Singkawang. Setelah fakta-fakta dapat dibuktikan di lapangan maka peserta didik dapat menyatakan pemecahan masalah yang dapat digunakan.

Dalam pelaksanaannya, strategi pembelajaran inkuiri mempunyai keunggulan yaitu melalui penelitian/penyelidikan yang langsung dilakukan oleh siswa dapat melatih para siswa untuk mengadakan penelitian secara ilmiah. Selain itu siswa akan memiliki semangat karena mereka benar-benar merasa sebagai subyek pendidikan sehingga lebih memungkinkan mereka merasa bangga terhadap hasil-hasil penelitiannya. Penekanan utama dalam proses belajar berbasis inkuiri terletak pada kemampuan siswa untuk memahami, kemudian mengidentifikasi dengan cermat dan teliti, lalu diakhiri dengan memberikan jawaban atau solusi atas permasalahan yang tersaji (Anam, 2017:8). Namun strategi ini memiliki kelemahan seperti waktu pelaksanaannya yang relatif lama (Supardan, 2015:204-205). Dalam penelitian/penyelidikan di lapangan, peserta didik dapat berinteraksi dengan orang atau narasumber, pelaku tradisi Cap Go Meh, para panitia dan pendukung acara, bahkan dengan penonton Cap Go Meh. Dengan strategi ini peserta didik dapat langsung berkomunikasi dengan masyarakat yang terlibat baik secara langsung maupun tidak langsung dalam tradisi Cap Go Meh, mengobservasi kegiatan Cap Go Meh, dan lain-lainnya.

Pemanfaatan tradisi lokal sebagai muatan lokal dalam pembelajaran IPS sejalan dengan lingkungan sosial di mana siswa itu berada sehingga menghasilkan output yang relevan dengan kebutuhan pembelajar sendiri (siswa) dalam hubungannya dengan masyarakat, dan kebutuhan masyarakat dalam hubungannya dengan yang belajar (siswa) (Sanusi, 2016:73). Melalui pembelajaran di atas, tujuan pendidikan sebagai suatu alat yang 
dapat menjaga kelestarian budaya akan tercapai sebagai aktualisasi nilai budaya bangsa.

4) Memberikan peluang bagi penciptaan produk keramik dengan motif-motif yang berasal dari etnis Melayu dan Dayak sebagai wujud alternatif motif keramik selama ini berupa motif naga. Sebagai contoh bisa menampilkan motif tudung saji dari Melayu dan motif burung enggang dari etnis Dayak.

5) Membawa siswa sekolah dasar sampai menengah (metode karya wisata) untuk mengunjungi tempat pembuatan keramik di Kota Singkawang bertujuan mengenal lebih dekat budaya yang dihasilkan oleh etnis lain sehingga timbul rasa penghargaan dan toleransi di kalangan siswa. Melalui kegiatan karya wisata, guru dan siswa melihat, mengamati, menghayati secara langsung dan nyata mengenai objek tersebut sehingga dapat menanamkan nilai moral pada peserta didik (Murtadlo dan Aqib, 2016: 99). Sikap, nilai, dan moral yang dapat dikembangkan adalah pengetahuan dan pemahaman tentang nilai dan moral yang berlaku dalam masyarakat, seperti religiusitas, penghormatan terhadap keteladanan, prestasi, sifat kepedulian sosial, menghormati orang tua, toleransi, kerjasama/gotong royong, dan hak asasi manusia (Hasan, 1996: 116).

Kunjungan siswa sekolah ke tempat pembuatan keramik ini dapat mengangkat nilai-nilai berupa pengakuan dan penghormatan, terhadap perbedaan (seperti kultural, agama, sosial, politik, dan pandangan hidup) (Lubis, 2016: 212). Cara tersebut dapat menimbulkan sikap toleransi sebagaimana diungkapkan oleh UNESCO (1998) terkait prinsipprinsip toleransi, yaitu a) toleransi sebagai proses pemahaman sejarah dan kebudayaan setiap kelompok, suku, agama, ras, lingkungan adat, dan bahasa; b) toleransi merupakan sikap menghormati perbedaan ciriciri khusus yang terdapat pada masing-masing kelompok, yaitu bentuk fisiknya, warna kulit, logat dan ucapan, sikap dan gaya pergaulan, adat-istiadat, cara beribadah dalam agama masingmasing; c) toleransi memanfaatkan perbedaan ciri khusus dalam upaya memperkokoh rasa kebangsaan karena akan saling memperkaya kebhinekaan; d) toleransi merupakan upaya membangun kepercayaan antarsesama anggota masyarakat dalam pemecahan masalah bersama secara damai, dalam berbagai bidang seperti bidang ekonomi, politik, dan budaya; e) toleransi upaya untuk memantapkan keadilan sosial dalam menghadapi perubahan yang cepat akibat teknologi dan ekonomi karena gelombang globalisasi (Tilaar, 2012: 81-82). Dengan sikap toleransi itu diharapkan peserta didik dapat memahami, menghargai, dan mampu bekerjasama dengan orang lain yang majemuk (Supriatna, 2007: 134).

Hal-hal tersebut, perlu diupayakan dalam rangka mempererat hubungan sosial di antara masyarakat Kota 
Singkawang dan juga dapat mencegah timbulnya kesenjangan budaya (cultural lag) karena terjadinya kesenjangan budaya dalam perubahan sosial, apabila terjadi adanya aspek budaya yang ketinggalan di belakang aspek budaya yang lainnya yang berkaitan dengan aspek budaya tadi (Ranjabar, 2017: 116). Dengan pengembangan sosial yang baik, dapat tercipta keharmonisan yang selaras dengan tujuan kehidupan masyarakat yang majemuk atau plural.

\section{PENUTUP}

Kota Singkawang merupakan kota yang majemuk atau plural dilihat dari segi etnis penduduknya. Kota yang mayoritas dihuni oleh etnis Tionghoa ini memiliki berbagai tradisi budaya yang berpotensi untuk dikembangkan secara sosial dan ekonomi. Kota ini memiliki tradisi yang kuat di bidang religi dan budaya. Terbukti dengan diselenggarakannya perayaan, seperti Imlek, Cap Go Meh, Sembahyang Kubur dari etnis Tionghoa, Gawai Dayak, Naik Dango dari etnis Dayak, dan Saprahan dari etnis Melayu. Selain itu, Kota Singkawang terkenal juga dengan industri keramiknya yang khas karena dibakar dengan cara tradisional dengan alat yang bernama tungku naga.

Dari perayaan Cap Go Meh dan industri keramik dapat menjadi potensi bagi pengembangan sosial ekonomi masyarakat Kota Singkawang. Melalui perayaan tradisi budaya dapat mempersatukan masyarakat Kota Singkawang yang majemuk. Dampak yang dirasakan sangat signifikan bagi pengembangan harmonisasi kehidupan masyarakat sekaligus sebagai potensi industri pariwisata yang mendatangkan pemasukan bagi penduduk Kota Singkawang, investor sehingga Pemerintah Kota Singkawang menghasilkan devisa untuk daerahnya. Dalam dunia pendidikan, dapat dimanfaatkan untuk materi muatan lokal sehingga para pelajar di Kota Singkawang dapat saling mengenal tradisi budaya etnis lain dan pada gilirannya dapat menciptakan generasi yang toleran, menghargai hasil karya kebudayaan etnis lain dan menumbuhkan jati diri sebagai bangsa yang Berbhineka Tunggal Ika.

\section{DAFTAR SUMBER}

Agusta, Ivanovich. 2014. Ketimpangan Wilayah dan Kebijakan Penanggulangan di Indonesia: Kajian Isu Strategis, Historis, dan Paradigmatis Sejak Pra Kolonial. Jakarta: Yayasan Pustaka Obor Indonesia.

Alma, Buchari. 2010. Pembelajaran Studi Sosial. Bandung: Penerbit Alfabeta.

Anam, Khoirul. 2017. Pembelajaran Berbasis Inkuiri: Metode dan Aplikasi. Yogyakarta: Pustaka Pelajar.

Andri, W.P. et al. 2008. Peta Tematik Kebudayaan dan Sejarah di Kalimantan Barat. Pontianak: Balai Pelestarian Nilai Budaya Pontianak.

Asmani, Jamal Ma'mur. 2012. Pendidikan Berbasis Keunggulan Lokal. Yogyakarta: DIVA Press. 
Aqib, Zainal. 2016. Model-Model, Media, dan Strategi Pembelajaran Kontekstual (Inovatif). Bandung: Yrama Widya.

Badan Pusat Statistik. Penduduk Menurut Wilayah dan Agama yang Dianut Provinsi Kalimantan Barat. sp2010.bps.go.id, diakses pada 13 Oktober 2017.

Banks, James A. 2012. Strategi Mengajar Ilmu Sosial: Penyelidikan, Penilaian, dan Pengambilan Keputusan. Bandung: Prodi PIPS SPS UPI dan Mutiara Press.

Gross, Richard E. 1978. Social Studies For Our Times. Canada: John Wiley \& Sons, Inc.

Gunawan, Rudy. 2016. Pendidikan IPS: Filosofi, Konsep, dan Aplikasi. Bandung: Alfabeta.

Haningsih, Sri. 2005. Esensi Pendidikan Islam Ditinjau Dari Pendekatan Multikultural. Jurnal Pendidikan Islam FIAI Jurusan Tarbiyah.Vol. XII, No. VIII, hlm. 927.

Hanum, Farida dan Sisca Rahmadonna. 2010. Implementasi Model Pembelajaran Multikultural di Sekolah Dasar Propinsi daerah Istimewa Yogyakarta. Jurnal Penelitian Ilmu Pendidikan.Vol. 03, No. 1, hlm. 89-102.

Hasan, S. Hamid. 1996. Pendidikan Ilmu Sosial. Jakarta: Depdikbud. http://id.m.wikipedia.org/wiki/ Kota_Singkawang, diakses pada 13 Oktober 2017.

Kartadinata, Sunaryo. 2015. Pendidikan Kedamaian. Bandung: PT. Remaja Rosdakarya.

Koentjaraningrat. 1993. Kebudayaan, Mentalitas, dan Pembangunan. Jakarta: PT. Gramedia Pustaka Utama.

Lubis, Akhyar Yusuf. 2016. Pemikiran Kritis Kontemporer: Dari Teori Kritis, Culture Studies, Feminisme, Postkolonial, hingga Multikulturalisme. Jakarta: PT. Rajawali Press.

Mahfud, Choirul. 2016. Pendidikan Multikultural. Yogyakarta: Pustaka Pelajar.

Mathews, S. A. dan P.P. Dilworth. 2008. Case Studies of Pre service Teachers' Ideas About the Role of Multicultural Citizenship Education in Social Studies. Theory $\&$ Research in Social Education. Vol. 36, No. 4, hlm. 356-390.

Murtadlo, Ali dan Zainal Aqib. 2016. Kumpulan Metode Pembelajaran Kreatif dan Inovatif. Bandung: Penerbit Satunusa.

Nuriyanto, Lilam Kadari. 2014. "Bimbingan Konseling Melalui Pendidikan Multikultural Terhadap Anak-Anak dan Remaja," dalam Penanggulangan Paham Radikalisme. Jurnal Konseling Religi: Jurnal Bimbingan Konseling Islam Vol. 5, No. 1, hlm. 19-40. 
Rahmayani, Any. 2009. Dinamika Industri Keramik Cina di Sakkok Kota Singkawang Tahun 1933 Sampai 2008. Pontianak: Balai Pelestarian Nilai Tradisional Pontianak.

2010. Permukiman Tionghoa di Singkawang Abad Ke-19 (Sejarah Kota Bercirikan Tionghoa). Pontianak: Balai Pelestarian Sejarah dan Nilai Budaya Pontianak.

.2014. Permukiman Tionghoa di Singkawang. Yogyakarta: Ombak.

Ranjabar, Jacobus. 2017. Perubahan Sosial: Teori-Teori dan Proses Perubahan Sosial Serta Teori Pembangunan. Bandung: Alfabeta.

Ratna, Nyoman Kutha. 2016. Metodologi Penelitian: Kajian Budaya dan Ilmu Sosial Humaniora Pada Umumnya. Yogyakarta: Pustaka Pelajar.

Rustanto, Bambang. 2016. Masyarakat Multikultur di Indonesia. Bandung: PT. Remaja Rosdakarya.

Sanusi, Achmad. 2016. Pendidikan untuk Kearifan: Mempertimbangkan Kembali Sistem Nilai, Belajar, dan Kecerdasan. Bandung: Penerbit Nuansa.

Sapriya. 2016. Pendidikan IPS: Konsep dan Pembelajaran. Bandung: PT. Remaja Rosdakarya.

Soedarto. 1994. The Traditional Ceramic of Singkawang, It's History and Meaning as One of
Our Cultural Heritage. Pontianak: STKIP Pontianak.

Supardan, Supardan. 2015. Pembelajaran Ilmu Pengetahuan Sosial: Perspektif Filosofi dan Kurikulum. Jakarta: PT. Bumi Aksara.

Supardi. 2014. Pendidikan Multikultural Dalam Pembelajaran Sejarah Lokal. Jurnal Pembangunan Pendidikan: Fondasi dan Aplikasi. Vol. 2, No. 1, hlm. 91-98.

Supriatna, Nana. 2007. Konstruksi Pembelajaran Sejarah Kritis. Bandung: Historia Utama Press.

\section{Ecopedagogy:}

Membangun Kecerdasan Ekologis dalam Pembelajaran IPS. Bandung: PT. Remaja Rosdakarya.

Sutopo. 2006. Metode Penelitian Kualitatif. Surakarta: Universitas Sebelas Maret.

Taniputera, Ivan. 2007. History of China. Yogyakarta: Ar-ruz Media.

Tilaar, H.A.R. 2012. Perubahan Sosial dan Pendidikan: Pengantar Pedagogik Transformatif untuk Indonesia. Jakarta: PT. Rineka Cipta.

Tohardi, Ahmad. 2003. Potret Pengusaha Etnis Tionghoa di Kalimantan Barat. Pontianak: Untan Press.

Tukiran. 2014. Pendidikan Multikultural dan 
Nasionalisme di Indonesia.

Jurnal Sosio Didaktika, Vol. 1 No. 1.

Usman, S. dan Din, I. 2008. Masyarakat Sejarah dan Kebudayaan Tionghoa di Kalimantan Barat. Pontianak: Pustaka PeDAS.

Utama, Eka Jaya Putra. 2013. Materi Sejarah dalam Buku Teks Muatan Lokal Pendidikan Multikultur Kalimantan Barat. Jurnal Socia: Jurnal Ilmu-Ilmu Sosial. Vol. 10, No. 2, hlm. 157166.

Widiarto, Tri dan Suwarso. 2007. Perspektif Global. Salatiga: Widya Sari Press.

Yoest. 2008. Riwayat Kelenteng, Vihara, Lithang di Jakarta dan Banten. Jakarta: PT. Bhuana Ilmu Populer. 